\title{
FUTEBOL E DRAMATICIDADE: NOTAS SOBRE A CRÔNICA ESPORTIVA DE NELSON RODRIGUES
}

\section{FOOTBALL AND DRAMATICITY: NOTES ABOUT NELSON RODRIGUES' SPORTS CHRONICLE}

\author{
Natasha Santos Lise ${ }^{*}$ \\ André Mendes Capraro ${ }^{* *}$
}

\begin{abstract}
RESUMO
O objetivo da presente pesquisa é localizar, historicamente, a crônica esportiva de Nelson Rodrigues, a partir do levantamento do estado da arte relacionado ao assunto, bem como da análise de algumas de suas crônicas. Para tanto, recorreuse ao tratamento das especificidades do gênero crônica, sob o ponto de vista da perspectiva de texto e contexto, organizada por Antonio Candido (1992; 2000). Junto a isso, partiu-se de uma breve biografia de Rodrigues, atrelando-a às particularidades de sua crônica esportiva. A título de conclusão, sugere-se que Nelson Rodrigues, até de forma inconsciente, escrevia defendendo a polêmica teoria do irmão, de que o racismo se manifestaria apenas em situações adversas - como a derrota em 1950. O que sugere, ainda, que o livro de cabeceira do dramaturgo não era Casa Grande \& Senzala, mas O Negro no Futebol Brasileiro.
\end{abstract}

Palavras-chave: Literatura; Esporte; Identidade nacional.

\begin{abstract}
The objective of the present research is to locate, historically, Nelson Rodrigues' sports chronicle, based on the bibliography related to the subject, as well as the analysis of some of his chronicles. In order to do so, we used the treatment of the specificities of the chronicle gender, from perspective of text and context, organized by Antonio Candido (1992; 2000). Along with this, it was necessary a brief biography of Rodrigues, linking it to the particularities of his sports chronicle. As a conclusion, it is suggested that Nelson Rodrigues, even unconsciously, wrote defending the polemic theory of his brother, that racism would manifest itself only in adverse situations - such as the defeat in 1950. This suggests, also, that book most read by Rodrigues was not Casa Grande \& Senzala, but O Negro no Futebol Brasileiro.
\end{abstract}

Keywords: Literature; Sport; National Identity.

"Doutoranda em Educação Física pela Universidade Federal do Paraná.

"Pós-doutor pela Università Ca Foscari Di Vanezia e Professor Associado do curso de Educação Física da Universidade Federal do Paraná. 


\section{INTRODUÇÃO - O FUTEBOL NA LITERATURA}

O presente estudo se refere a um recorte da pesquisa desenvolvida pelos autores ao longo da dissertação de mestrado ${ }^{1}$, em que se buscava analisar não apenas as crônicas esportivas, como também os roteiros e contos produzidos por Nelson Rodrigues. Nesse sentido, o objetivo aqui proposto é localizar, historicamente, a crônica esportiva rodrigueana, a partir do tratamento da bibliografia relacionada ao assunto, bem como da análise de algumas de suas crônicas. Dessa forma, recorreu-se à abordagem metodológica desenvolvida por Antonio Candido (1992; 2000), no que se refere às características próprias da crônica, enquanto um gênero literário híbrido, que reproduz certo amálgama entre aspectos textuais e contextuais.

Pois bem. O contato desde muito cedo com as tragédias literárias, os escândalos da vizinhança e as atmosferas do meio jornalístico, fariam com que Nelson Falcão Rodrigues adquirisse traços em sua escrita que dificilmente se afastariam da morbidez. De acordo com o próprio autor, ao rememorar sua infância, com cerca de oito anos de idade descreveria um assassinato brutal. Tratava-se de um concurso de redação da classe, em que os alunos estariam livres para desenvolver qualquer assunto. Nelson falaria de um tema inédito na turma.

Minha composição era todo um gesto de amor desesperado. Eu escrevia para a professora, isto é, para o ser amado. E me lembro de que começava assim:"A madrugada raiava sangüínea e fresca". Confesso que fiz o plágio com um secreto terror.

[...] Com oito anos incompletos, eu contava um adultério, com todos os matadouros. O marido saía e a mulher, nas barbas indignadas dos vizinhos, chamava o amante.

Eu era um moralista feroz. E não fui, confesso, nada compassivo. Um dia, o marido volta mais cedo. Ao entrar em casa, vê aquele homem saltar da janela, pular o muro e sumir. A mulher caiu-lhe aos pés, soluçando: - "Não me mate! Não me mate!". O marido agarrou-a pelos cabelos. E o que houve, em seguida, foi uma carnificina. Lembro-me de que a composição terminava assim: - "Acabou de matá-la a pontapés".

\footnotetext{
${ }^{1}$ A dissertação em questão é intitulada "Freud explicaria isso? Os sentimentos e ressentimentos do futebol em Nelson Rodrigues (1951-70)".
}

A professora acabou de ler e olhara para mim, aterrada (RODRIGUES, 1967. In: Rodrigues, 1993, p 145-146).

Segundo Rodrigues, o plágio se referia apenas à primeira linha do texto ("A manhã raiava sangüínea e fresca"), que pertencia a um soneto de Raimundo Correia, sugerindo que o restante da história, isto é, toda a parte funesta tenha sido criada por ele próprio. Pode ser que o pequeno autor tivesse se lembrado de alguma conversa entre os pais, ou de algum episódio na Rua Alegre, ou mesmo alguma matéria jornalística a que tenha tido acesso.

E é sob essa linha dramática que Nelson Rodrigues desenvolve suas produções, mesmo em se tratando do gênero crônica. Uma de suas características textuais se refere a trazer para os fatos “(...) um toque ficcional estilístico para que adquirissem um sentido transcendente e, consequentemente, alcançassem uma dimensão mítica" (SOUZA, 2006, p.13). Rodrigues demonstra em seus textos um desagrado com a realidade, denunciando a decadência do ser humano que vive angustiado e infeliz, sempre em busca de algum elemento que amenize o mal-estar. Logo, suas explanações, mesmo que a respeito de fatos cotidianos e personagens reais, via de regra, são passionais, acompanhadas de uma estrutura estética ímpar, carregada de imaginação.

De acordo com o inventário de Marcos de Souza (2006), quando Rodrigues inicia a jornada como cronista esportivo - em 1955 nos periódicos Última Hora e Manchete Esportiva -, era, além de polêmico, um reconhecido dramaturgo. Já contava com a encenação de $A$ Mulher sem Pecado (1941); com a consagração pela peça Vestido de Noiva (1943); com as censuras de Álbum de Família (1945), Anjo Negro (1946) e Senhora dos Afogados (1947); com o fracasso de público que foi Doroteia (1949); com um monólogo em Valsa $N^{o} 6$ (1951); e com a estreia de sua tragédia carioca $A$ Falecida (1953). Isso sem contar a já estabelecida coluna $A$ Vida Como Ela É... no jornal Última Hora, para o qual escrevia desde 1951.

Apesar de ser considerado um dos grandes contribuidores do desenvolvimento do teatro brasileiro, Nelson Rodrigues precisava escrever outros gêneros para sobreviver, o que lhe forçou a acumular, então, as colocações de cronista, contista, teatrólogo e, ainda, folhetinista. Sob os pseudônimos de Suzana Flag 
e Myrna, Rodrigues escreveu folhetins, com alguns intervalos, desde a primeira metade da década de 1940 até 1955, quando se iniciariam suas publicações na página esportiva. Os romances foram um sucesso de tiragem, passando por periódicos como as revistas A Cigarra, O Cruzeiro, os jornais Diário da Noite, Última Hora, O Jornal, acabando na eternidade das páginas do livro - o que indica que, muito provavelmente, fora o sucesso como folhetinista que rendera ao autor a posição fixa tanto na coluna de $A$ Vida Como

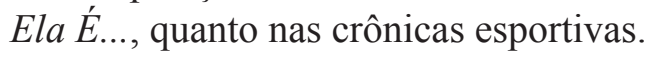

O fato de o teatrólogo paradoxalmente não ter conseguido ganhar dinheiro com o teatro se deu de maneira tensionada ${ }^{2}$, pois, em se tratando especialmente das décadas de 1940 e 50, havia um esforço por parte de intelectuais em romper com o modelo do chamado "teatro comercial" - isto é, que se preocupava primordialmente com o público pagante (PEREIRA, 1998). Nelson Rodrigues, apesar de ter confessado que seu interesse pelo teatro, em um primeiro instante, fora financeiro, fazia parte dos que defendiam o desenvolvimento do teatro nacional, independentemente do gosto da plateia, buscando o reconhecimento intelectual. Assim, tendo em vista a improvável possibilidade de se sustentar por meio do teatro, este irá aparecer imbricado em tudo o que o autor escrevesse.

Nesse sentido, uma particularidade do autor, incomum a outros cronistas, é a criação de personagens imaginários - sendo alguns inventados a partir de personalidades reais - na crônica esportiva. Tal é o caso do "Sobrenatural de Almeida", personagem clássico que sempre aparecia para explicar uma jogada futebolística inexplicável, fosse esta um gol esquisito ou mesmo um resultado inesperado. Assim como o "Sobrenatural de Almeida", as demais personagens - como o "Gravatinha", a célebre "Grã-fina das narinas de cadáver", o "Padre de Passeata", os "Idiotas da Objetividade" ou as "Estagiárias de Jornal", por exemplo - eram frequentemente lembradas nas crônicas, tornando-se familiares ao público.

Essa característica de incluir personagens e dramaticidade nas crônicas esportivas está diretamente vinculada a uma peculiaridade rodrigueana o trânsito entre um gênero literário e outro. Parte-se

\footnotetext{
${ }^{2}$ Para mais detalhes, ver: SANTOS, Natasha. Freud explicaria isso? Os sentimentos e ressentimentos do futebol em Nelson Rodrigues (1951-1970). Curitiba, 2012. Dissertação (Mestrado em História) - Departamento de História da Universidade Federal do Paraná, 2012.
}

da hipótese de que Nelson Rodrigues se considerava mais dramaturgo do que cronista, entretanto, pela impossibilidade de se dedicar de maneira efetiva ao teatro, transformaria o futebol, na crônica esportiva, e mesmo as matérias da coluna de $A$ Vida Como Ela É... em "palcos" onde reinaria o drama teatral. Daí os personagens fictícios nas crônicas - como os supracitados -, ou mesmo nuances de rubricas dos roteiros nos contos.

Em fins da década de 1930, bem como ao longo das de 40 e 50, prevalecia em torno do futebol a iniciativa de um elemento autenticamente nacional, cujas raízes foram estabelecidas por Gilberto Freyre - em sua reflexão sobre as relações entre a casa-grande e a senzala -, e disseminadas por cronistas esportivos, baseados no exemplo do futebol (HELAL, GORDON JR, 2001). Entre os principais literatos freyreanos, estão José Lins do Rego, Mário Filho e também Nelson Rodrigues. Cabe ressaltar que a passagem do futebol ao profissionalismo, que corresponde, sobretudo, ao cenário da década de 1930, era um momento em que se consolidava não só o esporte, mas também, a crônica esportiva (MARQUES, 2000). Segundo a ideia recorrente, pautada na campanha promovida por Nelson Rodrigues, a crônica esportiva se estabeleceria, definitivamente, devido à considerável contribuição de Mário Filho, entre as décadas de 40/50. Perspectiva esta aderida por muitos autores:

O percurso percorrido pelo futebol entre o amadorismo e o profissionalismo tem sua similaridade na trajetória da imprensa esportiva. Até o início da década de 40, o cronista esportivo ocupava a posição mais baixa na hierarquia dos jornais. Com a atuação de Mário Filho, houve a valorização do métier do analista e do repórter esportivo, a partir de seu trabalho com a promoção de competições, eventos, notícias e fatos - em suma, do próprio espetáculo. A invenção do profissional, donde temos uma múltipla simbiose: o jornal a criar a demanda para a produção do evento, e este a fornecer elementos para a atuação do homem na imprensa esportiva (MARQUES, 2000, p.17).

É nesse contexto que o futebol, enquanto objeto nacional, se insere como uma tradição inventa$\mathrm{da}^{3}$ (HOBSBAWM; RANGER, 1997), estabelecida e

\footnotetext{
${ }^{3}$ Por 'tradição inventada' entende-se um conjunto de práticas, normalmente reguladas por regras tácitas ou abertamente aceitas; tais práticas, de natureza ritual ou simbólica, visam inculcar certos valores e normas de comportamento
} 
reforçada por literatos ${ }^{4}$, através das crônicas ${ }^{5}$, principalmente. A partir da observação do que vinha a ser um fenômeno social das massas, intelectuais passaram a refletir sobre alguns dos dilemas envoltos na sociedade brasileira, expressando-se por meio de produções artísticas das mais variadas - embora não fosse comum à época, podem-se citar aqui peças teatrais, contos, romances, poesias e mesmo pinturas.

Assim como Mário Filho, José Lins do Rego mantinha uma relação bastante próxima a Gilberto Freyre, permeada por uma admiração recíproca. O primeiro defendia o futebol de maneira "radical", tratando de questões da constituição da raça e identidade brasileiras, bem como reafirmando a história do futebol de maneira quase literária, aos moldes dos ensaios produzidos por Freyre. Ao título de O Negro no Futebol Brasileiro, Mário Filho buscou mostrar a participação do futebol na formação de uma nação integral, a partir das relações raciais no esporte que, para o autor, teriam superado as tensões uma vez existentes. É o que explicam Helal e Gordon Jr:

Como num quebra-cabeça, partindo de "causos" (alguns talvez fictícios) da tradição oral do futebol, Mário Filho teria recortado e montado uma estrutura narrativa, cujo objetivo era mostrar como o futebol teve uma participação decisiva na democratização racial e, portanto, na construção de uma nação integral (HELAL, GORDON JR, 2001, p.53).

Tal narrativa acerca do futebol une as lembranças pessoais do autor a depoimentos orais de jogadores, e é com base neste ensaio que José Lins do Rego e Gilberto Freyre enxergam dois fenômenos derivados do futebol - o legado étnico negro e a música incorporada ao modo de jogar (HOLLANDA, 2003). Desse modo, um dos principais elementos identitários colocados é a miscigenação brasileira, que antes causava vergonha e era tratada como responsável pelo atraso do país, mas que, no futebol, teria se caracterizado como o motivo dos bons resultados diante dos demais países (SOARES; LOVISOLO, 2003). Freyre debate não apenas sobre a necessidade de se estabelecer uma

através da repetição, o que implica automaticamente uma continuidade em relação ao passado. Aliás, sempre que possível, tenta-se estabelecer continuidade com um passado histórico apropriado (HOBSBAWM, RANGER, 1997, p.9). ${ }^{4}$ Tais como Coelho Netto, João do Rio, José Lins do Rego, Mário Filho, Armando Nogueira (CAPRARO, 2007).

${ }^{5}$ Pode-se entender a crônica como um gênero híbrido, representando uma mistura entre jornalismo e literatura, que deriva dos folhetins (CANDIDO, 1992). identidade brasileira, mas também, elaborou uma tese a respeito do que viria a ser uma brasilidade, pautada na cultura, representada por comportamentos como a malemolência e a criatividade. É neste sentido que a escolha do futebol como expressão do povo brasileiro se encontra com a perspectiva freyreana: como um traço essencial e positivo da formação da sociedade brasileira (FACINA, 2004).

Ora, Nelson Rodrigues mantinha laços estreitos a Freyre, Zé Lins e Mário Filho, além de ser um apaixonado pela seleção brasileira, tratando-a como a própria pátria em chuteiras, possivelmente num amálgama entre sua paixão de torcedor e a defesa de uma identidade nacional.

\section{A CRÔNICA ESPORTIVA RODRIGUEANA}

Vejam vocês em que dá a mania da justiça e da objetividade! Um cronista apaixonado havia de retocar o fato, transfigurá-lo, dramatizá-lo. Daria à estúpida e chata realidade um sopro de fantasia. Falaria com os arreganhos de um orador canastrão. Em vez disso, os rapazes cingiram-se a uma veracidade parva e abjeta. Ora, o jornalista que tem o culto do fato é profissionalmente um fracassado. Sim, amigos, o fato em si mesmo vale pouco ou nada. $\mathrm{O}$ que lhe dá autoridade é o acréscimo da imaginação (RODRIGUES, 1994, p. 11-12). 6

\section{O gênero literário, o esporte e um ideal identitário}

Nelson Rodrigues, filho do polêmico jornalista Mário Rodrigues, desde muito cedo desempenhou pequenas funções ${ }^{7}$ nos jornais do pai. No último deles, o sensacionalista Critica, Nelson trabalhava na página policial, colhendo depoimentos na cena do crime e os retratando na notícia com certo grau de ficção, a fim de tornar as histórias mais interessantes (CASTRO,

\footnotetext{
${ }^{6}$ Originalmente: O passarinho, Manchete Esportiva, 31 mar. 1956.

${ }^{7}$ Já em 1925, Nelson Rodrigues trabalhava na página policial do jornal $A$ Manhã, do qual Mário Rodrigues era sócio. No começo, sua função era apenas fazer a ronda das delegacias por telefone, mas também escreveu algumas matérias. Em 1926, criou o seu próprio jornal, que sobreviveu cinco números: $A$ Alma Infantil, que seguia os padrões do jornal do pai e era, inclusive, impresso nas máquinas de A Manhã. No jornal Critica, Nelson Rodrigues compunha a "Caravana do Critica", escrevendo as matérias policiais, bem como indo ao local do crime (especialmente quando se tratava de um crime passional), para a obtenção de informações (CASTRO, 1992).
} 
1992). Antes disso, em A Manhã, o jovem repórter de apenas 13 anos já se deslumbrava, sobretudo, com os casos de crimes passionais - em especial, pactos de morte entre casais -, que lhe despertaram uma atração que permaneceria em sua vida adulta, sendo frequentemente retratada em seus contos e roteiros.

Já na década de $1930^{8}$, Nelson Rodrigues foi repórter esportivo do jornal $O$ Globo, porém os textos não eram assinados, sendo necessário recorrer às particularidades da escrita ou mesmo às fotos, do repórter e do entrevistado, dispostas ao lado da matéria (SOUZA, 2006). Entretanto, de acordo com o inventário da obra rodrigueana, elaborado por Marcos Francisco de Souza (2006), é a partir da metade da década de 1950, que o já conhecido dramaturgo se (re)apresenta como cronista. Ainda segundo Souza, os periódicos que publicaram as crônicas de Rodrigues foram: o jornal Última Hora e a revista Manchete Esportiva, a partir de 1955; o Jornal dos Sports, no qual inaugura a coluna diária em 1958; o jornal Diário da Noite, entre 1961 e 62; retornando para $O$ Globo nos anos 1960 e 70 (SOUZA, 2006, p.64).

Assim como muitos outros escritores - como Carlos Drummond de Andrade, Machado de Assis, José de Alencar, João do Rio, José Lins do Rego, Mário e Oswald de Andrade -, Nelson Rodrigues não se dedicou exclusivamente à crônica. Talvez essa ausência de exclusividade voltada a tal gênero se explique pelo fato de este possivelmente representar uma maneira de complementar a renda mensal ${ }^{9}$, ou mesmo por não se tratar de um "gênero maior", o que prejudicaria o reconhecimento do literato no meio intelectual.

Ora, a crônica, tratada como um gênero literário de "menor grandeza" - tendo em vista sua posição na intersecção entre literatura e notícia -, nasceu do jornal e, portanto, uma de suas principais características é exatamente a mesma efemeridade atribuída às manchetes. Sobre a origem da crônica moderna, Antonio Candido (1992) coloca o decênio de 1930 como o momento quando esta se estabelece no Brasil. Enquanto um gênero genuinamente brasileiro, a crônica teria derivado dos folhetins, os quais foram reduzindo de

\footnotetext{
${ }^{8}$ Tem-se, ainda, a referência de três crônicas publicadas no jornal da família Rodrigues, o Critica, em 1929. Tais textos fazem parte da coletânea organizada por Nelson Rodrigues Filho, intitulada "O Profeta Tricolor - cem anos de Fluminense", de 2002.

${ }^{9}$ Entre os poucos literatos que se dedicaram exclusivamente à crônica (esportiva), pode-se citar Rubem Braga, Paulo Mendes Campos e João Saldanha (CANDIDO, 1992; CAPRARO, 2007).
}

tamanho e deixando de informar, ou comentar, para apenas divertir - muito embora não deixe completamente de fazê-lo.

Apresentando-se como literatura de fronteira (GINZBURG, 2004), as crônicas colocam aos leitores a tênue relação entre ficção e realidade, entre a literatura e o acontecido no dia anterior, sendo "[...] de alguma maneira o tempo feito texto, sempre e de formas diversas, uma escrita do tempo. Não fosse senão por essa razão, já seria justo que delas se ocupassem os historiadores" (NEVES In Candido, 1992, p. 82). Não trazendo, portanto, um distanciamento tão enfático do cotidiano.

Mesmo podendo sair do tabloide para o livro e se eternizar, a crônica traz uma linguagem bastante próxima àquele: não tão literária, mas também não tão objetiva. Haja vista a amplitude de seu público, utiliza uma linguagem pouco carregada, sendo mais acessível sua compreensão. Assim, "Num país como o Brasil, onde se costumava identificar a superioridade intelectual e literária com grandiloqüência e requinte gramatical, a crônica operou milagres de simplificação e naturalidade, que atingiram o ponto máximo nos nossos dias (...)" (CANDIDO, 1992, p. 16). E é a partir dessa leveza de linguagem que ela se torna mais acessível e, por consequência, comunica de maneira mais efetiva sobre a visão do dia-a-dia (isto é, dos fatos). Desse modo, a crônica se fixaria como um ótimo catalisador não só de informações, mas também de teses, ideais e opiniões.

Mas, assim como os demais gêneros literários, ela carrega as particularidades do autor, cujos estilos vão de diálogos a biografias líricas e anedotas desdobradas (CANDIDO, 1992). E esse é o ponto essencial da crônica rodrigueana. Nelson Rodrigues se utiliza dos máximos elementos fictícios, inserindo, inclusive, personagens, como os célebres Sobrenatural de Almeida, a Grã-fina das Narinas de Cadáver ou o Gravatinha. Incorporando traços do teatro - sua principal atividade literária -, o autor faz mais do que enaltecer/criticar as vitórias/derrotas da seleção brasileira ou do Fluminense: ele estabelece as emoções decorrentes de cada situação, indo para além do esporte.

Sobre a peculiaridade ao escrever crônicas, José Marques (2000) propõe o que seria uma "filiação" de Nelson Rodrigues à estética neobarroca, teorizada por Severo Sarduy e posteriormente por Omar Calabrese. Analisa, portanto, não o papel do futebol em si, mas 
de que maneira se dá a manifestação de elementos do neobarroco - cujo conceito define e defende características de uma cultura miscigenada - na crônica esportiva deste literato.

Essa estética barroca, de que fala Marques, se estabelece na crônica de Rodrigues sob o exagero textual, carregado de uma hipérbole tão exagerada a ponto de tornar o futebol mais importante do que os problemas sociais. Ou seja, "O excesso nas crônicas de Nelson serve assim como superação de limites e como espaço desestabilizador" (MARQUES, 2000, p.134). Esse exagero é tratado por Silva (1997) como uma peculiaridade do que denomina "orador canastrão", mais preocupado em "retocar" os fatos, do que em relatá-los tal como ocorreram. Assim, o principal recurso retórico seria o discurso persuasivo que, no caso desse literato, se mantém sob a ótica de um cronista apaixonado, que escrevia como torcedor, ou seja, de maneira nada objetiva. Segundo as palavras do próprio autor, nas crônicas de Nelson Rodrigues,

[...] faz-se uma utilização engenhosa, radical e deliberada dos recursos retóricos, e todo o discurso se organiza em função da persuasão. Ciente de que a realidade dos fatos esportivos não é nada mais do que uma construção, Nelson se move abertamente no campo da opinião: a sua opinião, a opinião dos torcedores, dos cronistas, a opinião pública, o senso comum (SILVA, 1997, p.103).

Todavia, não se pode esquecer que o autor era um cronista esportivo e, como tal, deveria atentar para os acontecimentos dos gramados e arquibancadas. Somado a isso, segundo Magaldi (2010), é possível perceber por meio dos roteiros rodrigueanos, uma determinada aversão à realidade, o que não é diferente em seus contos e crônicas. Daí o exagero literário com requintes tão estéticos que se aproximam da ficção, que neste caso seria o futebol como maior que os problemas sociais, em um período em que o esporte em si não era reconhecido como um assunto "sério". Muito pelo contrário, não raro alguns literatos ou intelectuais não o consideravam um assunto sério exatamente porque o ignoravam. São os casos de Sérgio Buarque de Hollanda, Caio Prado, o grupo intelectual da USP Fernando Henrique Cardoso, Ruth Cardoso, Florestan Fernandes, Otavio Ianni e o próprio Antonio Candido. Na literatura - Érico Veríssimo (embora o filho venha a gostar do futebol), José Mauro de Vasconcelos (Meu
Pé de Laranjas Lima), Antonio Callado (Quarup), entre vários outros.

Sob estas perspectivas, a crônica esportiva (via de regra, futebolística) desenrola, sobretudo nas décadas de 1940 e 50, um alinhamento freyreano no que diz respeito à relação entre o futebol e a identidade nacional.

Um dos principais elementos identitários colocados é a miscigenação brasileira, que antes causava vergonha, mas que, no futebol, teria se caracterizado como o motivo dos bons resultados diante dos demais países (SOARES; LOVISOLO, 2003). Mário Filho, ao tratar do negro no futebol brasileiro, não disseminou apenas a tese freyreana, mas também, e principalmente, o já citado "freyrismo popular" (SOARES, 2003).

Entre os principais literatos freyreanos, além de Mário Filho, estão José Lins do Rego e, por maior influência daquele, Nelson Rodrigues. Estabelecendose, assim, a crença em uma característica tipicamente brasileira ao jogar futebol, baseada na agilidade e improvisação, que diferenciava os jogadores nacionais dos demais, enaltecendo a mestiçagem e malandragem.

No caso brasileiro, o esporte em questão foi colocado e reforçado por literatos - através das crônicas, em especial -, como uma prática essencialmente nacional, cujas peculiaridades brasileiras seriam a ginga, a malícia e o improviso no jogo (SOARES, 2003). A partir da observação do esporte enquanto um fenômeno social das massas, intelectuais passaram a refletir sobre dilemas envoltos na sociedade brasileira, expressando-se por meio de produções artísticas das mais variadas.

Assim, as proposições "popularizadas" de Gilberto Freyre, no que concerne ao homem negro e mestiço, bem como à sua singularidade no esporte, ganham força e são reafirmadas por literatos brasileiros, via jornais, principalmente. Freyre influenciou uma geração de literatos e contribuiu para uma nova interpretação do Brasil, segundo a qual a figura do mestiço se fazia valer nas representações futebolísticas (SOARES, 2003).

Mas o que levou literatos, como Nelson Rodrigues, a comprarem e disseminarem tal tese? Ora, "como figuras públicas, os literatos necessitavam estabelecer relações de força visando respaldá-los dentro do campo literário / intelectual" (CAPRARO, 2007, p. 
8), o que implica, sob a perspectiva ideológica destes intelectuais, a formação de um vínculo, que acarreta comportamentos e atitudes interdependentes (ELIAS, 1994). Nesta perspectiva, Gilberto Freyre seria o grande influenciador de José Lins, Mário Filho e Nelson Rodrigues, mantendo uma admiração que se fazia recíproca, a qual acabaria por ser estendida a Nelson pelo vínculo afetivo com o irmão Mário. Desse modo, pode-se pensar, assim como aponta André Capraro (2007), em uma relação de força favorável a Freyre que, além de deter o respaldo dos cronistas em questão, no meio literário, teve seu modelo explicativo popularizado através do futebol.

Retornando ao embasamento do estudo de Capraro (2007), infere-se que a essência da unidade desses intelectuais era, sobretudo, afetiva. Assim como José Lins - que trocava cartas com Gilberto Freyre -, Mário Filho mantinha uma relação muito próxima ao intelectual, chegando a adaptar sua narrativa acerca da ascensão do negro por meio do futebol à teoria freyreana. Em O Negro no Futebol Brasileiro, de 1947, Mário Filho estabelece uma interpretação da tese de Freyre, culminando com o que seria, tal como aponta Soares (2003) um "freyrismo popular", ao defender que no Brasil as relações entre negros e brancos seria pacífica, não havendo, portanto, racismo. Além disso, conta-se com pistas como as declarações públicas de afeto de Nelson Rodrigues a Mário Filho, conferindo-lhe a imagem de grande homem da imprensa esportiva... "Eis o papel do meu irmão Mario Filho, diretor de 'Jornal dos Sports': - o de criador dos fatos. (...) Que fez Mario Filho, no fabuloso mundo dos esportes? Criou seus fatos próprios, seus assuntos exclusivos" (RODRIGUES, 13 set. 1955, p.8).

E é aqui que entra a importância de Nelson Rodrigues: tendo em vista as mortes, de certa forma prematuras, de José Lins e Mário Filho, o teatrólogo acabou por prosseguir associando futebol e nação. E mais, se pensada a popularidade de Nelson Rodrigues, tendo em vista sua posição enquanto escritor dos contos de A Vida Como Ela É..., diariamente publicados em jornais, além, é claro, das polêmicas causadas por suas peças incestuosas, é deveras sensato supor que os ideais expostos nas crônicas atingiriam um público maior.

Mesmo antes das vitórias nos Mundiais de 1958 e 1962, Nelson Rodrigues tratava o futebol como uma das paixões do povo brasileiro. Os discursos, carregados de uma nacionalidade apaixonada, se faziam presentes mesmo nas derrotas da seleção brasileira, pois, para Rodrigues, o país sempre teve o melhor selecionado do mundo. "Basta lembrar o que foi o jogo Brasil x Hungria, que perdemos no Mundial da Suíça. Eu disse 'perdemos' e por quê? Pela superioridade técnica dos adversários? Absolutamente. Creio mesmo que, em técnica, brilho, agilidade mental, somos imbatíveis" (RODRIGUES, 2007, p.66) ${ }^{10}$.

A José Olympio - maior editora entre as que se firmam na década de 1930 (OLIVEIRA, 2003) - se tornou um ponto de encontro de grandes nomes da literatura brasileira. Entre os escritores, de variados gêneros, a editora contava com: José Lins do Rego, Mário Filho, Nelson Rodrigues, Otto Maria Carpeaux, Álvaro Lins, João Condé, Graciliano Ramos, Carlos Drummond de Andrade, Rachel de Queiroz, Jorge Amado, Aurélio e Sérgio Buarque de Holanda, além de Gilberto Freyre, cujas visitas à editora eram frequentes (CASTRO, 1992; HOLLANDA, 2004; ANTUNES, 2004; CAPRARO, 2007). Soma-se a tal fato, a aliança entre Getúlio Vargas e Samuel Wainer na fundação do jornal Última Hora (FERREIRA, 2008), onde Nelson Rodrigues escreveu os contos quase diários de $A$ Vida Como Ela É..., entre os anos de 1951 e 1961, bem como algumas crônicas esportivas.

Assim, mesmo que Nelson Rodrigues buscasse uma postura não tão contundente em relação à política - tendo em vista o empastelamento do jornal do pai, com a Revolução de 1930 (CASTRO, 1992) -, acabava por coincidir com alguns dos ideais de unificação nacional que se iniciam com Vargas e se sobressaem com Juscelino Kubitschek. Tais elementos também eram debatidos pelos escritores com quem Rodrigues se relacionava, mas o diferencial do teatrólogo estava na emoção que sempre vinha atrelada a tais elementos.

Pois bem, são nas linhas de Manchete Esportiva que Nelson Rodrigues estabelece um estilo próprio de crônica, fazendo uma mescla de comentários sobre o jogo e observações comportamentais.

Eis outro motivo que justifica o exagero literário: se escrever crônicas esportivas era mais rentável que as peças censuradas, por que não levar a teatralidade ao futebol? É nesse sentido, lapidando os fatos futebolísticos, que o dramaturgo estabelece o esporte: naquilo que seria a limiar entre a imaginação e os

\footnotetext{
${ }^{10}$ Originalmente: Manchete Esportiva, 07 abr. 1956.
} 
lances do jogo. Distorcendo e distanciando acontecimentos esportivos para enquadrá-los sob uma lógica de significação (SILVA, 1997). Nesse sentido, Marques sugere que, mais do que apenas textos, o autor de "Álbum de Família" produzia "narrativas de futebol", de construção puramente literária.

Ora, Fátima Antunes (2004), ao analisar as constituições representativas de identidade nacional, também aponta para esse exagero, que, de acordo com a sua análise, é compatível à "teatralidade" impressa na crônica esportiva rodrigueana. O que faz muito sentido, porque:

Nelson não deixa de mostrar-se sensível às questões sociais, expondo as conseqüências da miséria no comportamento de suas criaturas, mas se apega particularmente aos mistérios insondáveis da aventura humana, ao sentido metafísico da finitude e suas implicações éticas, à razão de ser da passagem terrena (MAGALDI, 2010, p.191).

Não se pode esquecer que Nelson Rodrigues era um teatrólogo que, embora não fossem altos os rendimentos dos cronistas, via a crônica como uma renda extra, e, inevitavelmente, levaria a dramaticidade com que tratava os mistérios humanos para a subjetividade do futebol. Mais do que o jogo, ele buscava descrever os instintos do atleta que guiava a bola.

Assim, para Nelson Rodrigues, o futebol seria embasado na fantasia e estabelecido pelo exagero de que os pesquisadores anteriormente citados tratam. Independentemente do resultado do jogo, a criação se faz quanto à identidade brasileira que, uma vez reconhecida, traz a vitória, sendo, assim, o fator determinante para o resultado de uma partida. O que se altera nas crônicas de Rodrigues não é a dinâmica do jogo em si, mas os momentos do brasileiro, que definiam uma partida linda ou trágica.

\section{CONCLUSÕES}

Cabe ressaltar que, de acordo com a análise de Antunes (2004), Rodrigues oscilou entre seus discursos, ora tratando o homem brasileiro como vencedor, ora falando da falta de organização que se refletia nos campos de futebol. Entretanto, sobretudo nos fins da década de 1950, o dramaturgo escrevia sobre o esporte de maneira solitária, uma vez que elaborava discursos ufanistas de apoio à seleção brasileira.
Nos estudos de Antunes (2004) e Marques (2000), pode-se perceber que a característica que difere Nelson Rodrigues dos demais cronistas da sua época - como Armando Nogueira, José Lins do Rego e Paulo Mendes Campos -, é exatamente a teatralidade que o autor imprime em seus textos. A marca do autor é exatamente essa autonomia artística, que sempre se faz presente em suas crônicas. Nesse sentido, a problemática de ambos os estudos se pauta na compreensão desta teatralidade, uma vez que, mantendo um forte compromisso com a estética textual, o autor de "Perdoa-me por me traíres" acaba por elaborar representações da nação brasileira, principalmente utilizando-se do futebol para tal.

Sendo assim, Marques (2000), que chama essa dramaticidade exagerada de "neobarroco", defende que essa estética se estabelece na crônica rodrigueana pelo exagero textual, que tornaria o futebol mais importante do que os problemas sociais. Tal como já exposto, não se pode esquecer de que Nelson Rodrigues era um teatrólogo que via na crônica uma maneira de subsistência e, enquanto cronista, dedicava-se à crônica esportiva.

Ortiz (1994), ao tratar das diferentes abordagens dadas à identidade nacional, variando no decorrer de períodos distintos, estabelece dois aspectos importantes que determinariam o conceito da identidade brasileira: o regime político e a interpretação do autor. Ora, a identidade nacional seria, portanto, correspondente a propostas e ideologias do regime vigente; entretanto, ao mesmo tempo, estaria sujeita ao modo com que cada autor - intelectual ou literato - se posiciona diante de tais ideais.

Nesse sentido, a título de conclusão, infere-se que, em se tratando das crônicas esportivas, pode-se dizer que a identidade nacional, segundo Nelson Rodrigues, se estabelece como uma interpretação dos preceitos de Gilberto Freyre, proposta por Mário Filho. Mesmo que não referenciasse suas obras, de maneira explícita, Nelson Rodrigues era partidário do enaltecimento do homem brasileiro que, para ele, tinha no mestiço a perfeita representação. $\mathrm{O}$ mulato era a personificação de uma brasilidade definida pela criatividade, agilidade, ginga e alegria, elementos que, tal como exposto anteriormente, se faziam visíveis ao longo das partidas de futebol. Vez ou outra, ele transitava pelo "homem cordial" de Sergio Buarque de Holanda (CAPRARO, 2007), entretanto para criticar 
a submissão do brasileiro, definida sob a figura do complexo de vira-latas, tão recorrente em seus textos, embora com atribuições que variam de acordo com a situação.

Pode-se supor que essa valorização do mulato, por meio do futebol brasileiro, estava mais vinculada a Mário Filho do que a Gilberto Freyre, e explica-se. Com a morte de Mário Rodrigues, em 1930, seguido pelo empastelamento do Critica, a família Rodrigues enfrentou muitas dificuldades financeiras (CASTRO, 1992), tal como aponta Nelson, em uma de suas memórias:

Ninguém queria empregar os filhos de Mário Rodrigues. Em vida de meu pai e enquanto circulou a Crítica, tínhamos amigos por toda parte. Eu era tratado, desde os treze anos, como um pequeno gênio. Mas morto Mário Rodrigues e morta a Crítica, os rapapés sumiram até o último vestígio. Ninguém era amigo. E adquiri, naqueles dias, uma experiência de Balzac. Todo mundo tinha medo e ódio de meu pai. O ódio era amável, era risonho, era cínico por causa do medo (RODRIGUES, 1967. In: Rodrigues, 1993, p.111).

E seria Mário Filho o primeiro a conseguir um emprego, sendo contratado por Roberto Marinho para dirigir a página esportiva de $O$ Globo, podendo assim auxiliar a família, bem como abrir caminho para seus irmãos.

Ficou assentado que, para dirigir a página de esporte de $O$ Globo, Mário ganharia 550 mil-réis mensais. Para a época, era um salário de primeiríssima ordem. Eu não ganhava um tostão e continuava desempregado. Mas, para ajudar meu irmão, passei a trabalhar como qualquer funcionário de $O$ Globo e mais que qualquer funcionário de $O$ Globo. Chegávamos eu e o Mário às sete da manhã; e saíamos às cinco da tarde (RODRIGUES, 1967. In: Rodrigues, 1993, p.118).

Por algum tempo, Mário Filho foi o responsável por manter, financeiramente, a casa, tornando-se, posteriormente, um reconhecido jornalista esportivo. Sob essa nova posição de Mário Filho, Nelson Rodrigues mantém uma quase infindável admiração pelo irmão, não só pela ajuda em tempos difíceis, mas também pelo profissional que se tornara. Assim, sob a perspectiva psicanalítica, pode-se falar em uma transferência da figura paterna, após a morte de Mário Rodrigues, para Mário Filho. Nesse sentido, é possível que a apropriação desse ideal de identidade se deu muito mais pelos vínculos afetivos (quase de louvor) em relação ao irmão, do que por influência direta (leitura das obras) de Freyre...

Meu Deus, gostaria de dar uma idéia da extensão, movimento e profundidade de sua obra. Quem era Mário Filho? Foi um desses homens fluviais, que nascem de vez em quando. Disse "fluvial" e explico: - imaginem um rio que banhasse e fertilizasse várias gerações. Assim foi Mário Filho. Durante quarenta anos, não houve cronista, não houve talento, vocação, em todo o Brasil, que não tenha sido por ele fecundado (RODRIGUES, 1967. In: Rodrigues, 1993, p.251).

Logo, sugere-se que Nelson Rodrigues, até de forma inconsciente, escrevia defendendo a polêmica teoria do irmão, de que o racismo se manifestaria apenas em situações adversas - como a derrota em 1950. O que sugere, ainda, que o livro de cabeceira do dramaturgo não era Casa Grande \& Senzala, mas O Negro no Futebol Brasileiro.

\section{REFERÊNCIAS}

ANTUNES, F. M. R. F. “Com Brasileiro Não Há Quem Possa": futebol e identidade nacional em José Lins do rego, Mário Filho e Nelson Rodrigues. São Paulo: Unesp, 2004.

CANDIDO, A. et. al. A Crônica. Campinas: Editora da Unicamp, 1992.

2000.

Literatura e Sociedade. São Paulo: Queiroz,

CAPRARO, A. M. Identidades Imaginadas: Futebol e Nação na Crônica Esportiva Brasileira do Século XX. Curitiba: Departamento de História da Universidade Federal do Paraná (Tese de Doutorado), 2007.

CASTRO, R. O Anjo Pornográfico. São Paulo: Companhia das Letras, 1992.

ELIAS, N. O Processo Civilizador. Rio de Janeiro: Jorge Zahar, 1994.

FACINA, A. Santos e Canalhas: uma análise antropológica da obra de Nelson Rodrigues. Rio de Janeiro: Civilização Brasileira, 2004.

FERREIRA, G. Crises da República: 1954, 1955, 1961. In: FERREIRA, J.; DELGADO, L. A. N. (Org.). O Brasil Republicano - O tempo da experiência democrática: da democratização de 1945 ao golpe militar de 1964. Livro 3. 2a ed. Rio de janeiro:Civilização Brasileira, 2008. 
GINZBURG, C. Nenhuma ilha é uma ilha: quatro visões da literatura inglesa. São Paulo: Companhia das Letras, 2004.

HELAL, R.; GORDON JR, C. Sociologia, História e Romance na construção da identidade nacional através do futebol. In: HELAL, R.; SOARES, A. J.; LOVISOLO, H. A Invenção do País do Futebol: mídia, raça e idolatria. Rio de janeiro: Mauad, 2001.

HOBSBAWM, E. A era dos extremos - o breve século XX (1914-1991). São Paulo: Companhia das Letras, 1995.

; RENGER, T. (org.). A Invenção das Tradições. Rio de Janeiro: Paz e Terra, 1997.

HOLLANDA, B. B. B. O descobrimento do futebol: modernismo, regionalismo e paixão esportiva em José Lins do Rego. Dissertação em História - PUC-Rio, 2003.

MAGALDI, S. Nelson Rodrigues: dramaturgia e encenações. São Paulo: Perspectiva, 2010.

MARQUES, J. C. O Futebol em Nelson Rodrigues. São Paulo: Educ/Fapesp, 2000.

OLIVEIRA, L. L. Sinais da Modernidade na Era Vargas: vida literária, cinema e rádio. In: FERREIRA, J.; DELGADO, L. A. N. (Org.). O Brasil Republicano - O tempo do nacionalestatismo: do início da década de 1930 ao apogeu do estado Novo. Livro 2. Rio de janeiro: Civilização Brasileira, 2003.

ORTIZ, R. Cultura Brasileira e Identidade Nacional. $5^{\text {a }}$ ed. São Paulo: Brasiliense, 1994.

PEREIRA, V. H. A. A Musa Carrancuda: teatro e poder no Estado Novo. Rio de Janeiro: Editora Fundação Getúlio Vargas, 1998.

SANTOS, Natasha. Freud explicaria isso? Os sentimentos e ressentimentos do futebol em Nelson Rodrigues (19511970). Curitiba, 2012. Dissertação (Mestrado em História) - Departamento de História da Universidade Federal do Paraná, 2012.

SILVA, M. R. O Mundo do Futebol nas Crônicas de Nelson Rodrigues. Dissertação em Letras - UFMG, 1997.

SOARES,A. J. Futebol Brasileiro e Sociedade: a Interpretação Culturalista de Gilberto Freyre. In: Futbologías. Fútbal, identidad y violencia en América Latina. Buenos Aires: Clacso, 2003.

SOUZA, M. F. P. S. F. Nelson Rodrigues - inventário ilustrado e recepção crítica comentada dos escritos do Anjo Pornográfico. Tese em Letras - UFRJ, 2006.

\section{FONTES}

RODRIGUES, Nelson. Meu irmão Mario Filho. Rio de Janeiro: Jornal Última Hora, 13 set. 1955, p.8.
. A Menina Sem Estrela: Memórias. São Paulo: Companhia das Letras, 1993.

. A Pátria em Chuteiras. São Paulo: Companhia das Letras, 1994.

O Berro Impresso das Manchetes. Rio de Janeiro: Agir, 2007. 